\section{Didkovskyi V., Zaets V., Kotenko 5.}

\title{
IMPROVEMENT OF THE EFFICIENCY OF NOISE PROTECTIVE SCREENS DUE TO SOUND ABSORPTION
}

Об'єктом дослідження є звукове поле від лінійних джерел звуку довкола шумозахисних екранів. Зменшення рівнів звуку за екраном в першу чергу обумовлено геометричними розмірами екрану та взаємним розташуванням екрана та джерела звуку. Впливу даних факторів приділялася велика кількість наукових публікацій. Однак проблемним місцем таких досліджень є те, що екрани вважались або повністю акустично жорсткими або звукопоглинальними.

В даній роботі розглянуто ситуацію імпедансного екрану, що досить часто застосовується на практиці. Розрахунок поля довкола такого екрану проводився засобами комп'ютерного моделювання, що дозволяє легко змінювати величину акустичного імпедансу поверхні екрану.

Для обчислення звукового поля довкола екрану було обрано метод скінченних елементів. Звукопоглинальні властивості екрана визначалися зміною акустичного імпедансу лищьової сторони екрана. При цьому екран залишався акустично непрозорим. Таким чином, було проведено аналіз впливу коефічієнта звукопоглинання на звукове поле довкола екрана за різних висот екрану та відстані джерел звуку до екрана. Це дозволило отримати результати рівнів звукового тиску довкола екранів, що зустрічаються в інженерній діяльності. Проведені дослідження показали, що використання звукопоглинального облицювання шумозахисних екранів дозволяє збільшити їх ефективність. Виявлено, що чим ближче екран розташовано до джерела звуку, тим більший вплив його звукопоглинальних властивостей. Показано, що для низьких частот збільшення ефективності екрану за рахунок звукопоглинання може сягати величини 5 дБ.

Отримані у ході дослідження результати можна використовувати при проектуванні шумозахисних екранів для зниження рівнів шуму від транспортних потоків. Особливо корисними отримані результати будуть при проектуванні екранів з висотами більше 4 м.

Ключові слова: шумозахисний екран, дифракція звуку, зменшення рівня звуку, імпедансні властивості, звукопоглинальний екран.

Received date: 30.01 .2020

Accepted date: 05.03.2020

Published date: 30.06 .2020

\section{Introduction}

Noise protective screens are one of the most effective ways to reduce the noise of various noise sources [1,2]. Throughout the world, the most common source of excessive noise is traffic, according to various sources, cover from $50 \%$ to $70 \%$ of the territory of settlements [3, 4]. Recently, much attention has been paid to the construction of new and reconstruction of existing transportation routes to increase the intensity of transportation and improve the safety of their operation. One of the requirements for the safe operation of any construction projects, which undoubtedly include road and rail tracks, is the requirement of «noise protection» [5].

As numerous studies show, the effectiveness of screens primarily depends on the height of the screen. The data [6] are presented that, with a screen increase of $1 \mathrm{~m}$, its efficiency increases by 1.5-2 dBA. However, the construction of high screens (with a height of more than $6 \mathrm{~m}$ ) is associated with great difficulties - an increase in wind and snow loads. This, in turn, leads to an increase in the size of load-bearing elements and foundations, and is reflected in excessive material costs.

Therefore, the search for ways to increase the effectiveness of noise protective screens with constant geometric dimensions is an urgent task, the solution of which will reduce material costs.
Copyright (c) 2020, Didkovskyi V., Zaets V., Kotenko S. This is an open access article under the CC BY license (http://creativecommons.org/licenses/by/4.0)

\section{The object of research and its technological audit}

The object of research is the sound field from linear sound sources around an impedance noise protective screen.

Noise protective screens installed along highways are usually made in the form of vertical walls with acoustically rigid materials and have a very low sound absorption coefficient.

The use of sound-absorbing cladding of screens has been little studied and therefore the influence of the coefficient of sound absorption of screens on the acoustic field around it is not fully understood.

\section{The aim and objectives of research}

The aim of research is to evaluate the effect of soundabsorbing properties of noise protective screens on its effectiveness.

To achieve this aim, it is necessary to complete the following objectives:

1. To determine the relationship of sound-absorbing properties of the screen and increase its effectiveness.

2. To determine the maximum possible increase in screen efficiency due to sound absorption. 


\section{Research of existing solutions of the problem}

The problems of using noise screens and finding their effectiveness in the world began to be dealt with from the mid-60s of the last century. Such studies are based on work [7], however, the experimental studies of the authors of this work were based on finding a noise screen without taking into account the influence of the earth. Later, laboratory studies were conducted of reducing the effectiveness of noise screens for point sources of sound and obtained approximate expressions for finding their effectiveness, taking into account the reflection of sound from the surface of the earth [8]. These studies were based on the theory of geometric acoustics, which led to a limitation of the scope of application of the obtained expressions in the low and medium frequencies.

With the development of computer technology, it became possible to conduct computer simulation of the acoustic field around the screen. The most widely used are the method of limit regions [9] and the finite element method [10]. It was shown in [11] that the method of limit domains can be applied to any geometric system with arbitrary boundary conditions, but the calculation will be a factor that limits the complexity of the system and is suitable for solving external problems. At the same time, the finite element method allows solving internal problems by dividing the decoupling region into elementary particles [12]. A common drawback of numerical methods is the uncertainty of the calculation error, and the most common way to assess the adequacy of a computer model is to compare the results of calculations with full-scale or with experiments.

In $[13,14]$, the use of screens with different geometry of edges was considered as one of the ways to increase the efficiency of noise protective screens. In this paper, it is shown that the use of various upper edges of the screen leads to an increase in their efficiency by up to $10 \mathrm{~dB}$. However, this value was obtained for discrete frequencies, while transport noise, as is known, is continuous in spectrum, and therefore the efficiency of using such diffusers is not proven.

One of the ways to increase the efficiency of screens is the use of sound-absorbing structures on the screen side, facing the sound source. Literature data [15] indicate an increase in screen efficiency due to sound absorption by up to $9 \mathrm{~dB}$, which is a very significant indicator. Other data presented in $[16,17]$ show that a decrease in the sound level behind the screen due to its sound-absorbing properties is not significant.

Thus, it is precisely the uncertainty in the estimates of the effect of sound absorption of the screen on its effectiveness that prompted the study of this issue. In addition, in connection with the practical design of screens, the authors of the work conducted a study of the effect of sound absorption of the screen on its effectiveness.

\section{Methods of research}

These tasks were solved by computer simulation. Using the Comsol Multiphysics software, a model of a reflective noise protective screen and a sound-absorbing screen was created. The acoustic field around the screens was found using the partial element method.

When solving wave problems, it becomes necessary to simulate a free field region - such a boundary of the computational domain through which acoustic waves would pass without any reflection (Fig. 1). For this model, the condition of perfectly matched layers was applied to limit the area of numerical modeling - perfectly matched layer (PML).

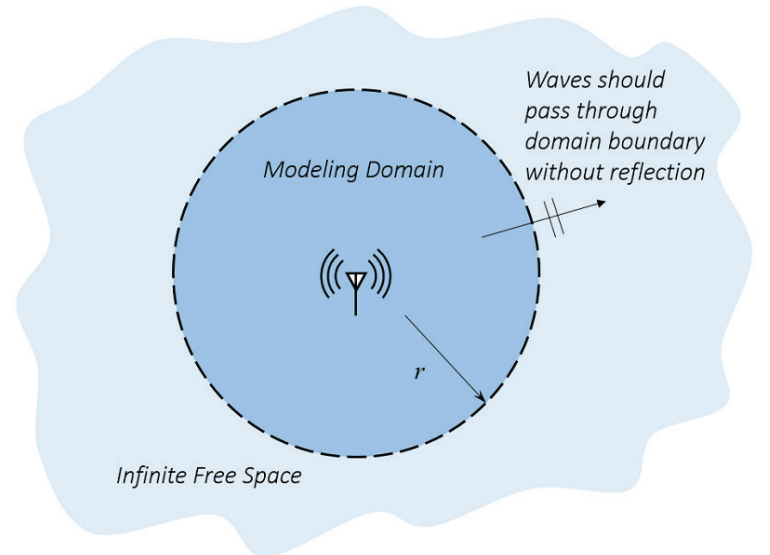

Fig. 1. Schematic representation of the PML condition

Thus, the use of PML allows to calculate the sound field from various sound sources in a limited area and not to take into account the reflection of sound from the boundaries of this area. This allows to build models of much smaller volume, reduces the resource costs for calculating the field without compromising the accuracy of the calculations.

\section{Research results}

6.1. Development of computer model. The next step was to build a two-dimensional geometry of a noise protective screen with a road and noise sources (Fig. 2). Models of the road were built on the example of highways of international importance in Ukraine, such as M-06 Kyiv - Chop, M-03 Kyiv - Kharkiv Dovzhanskyi, M-05 Kyiv - Odesa, for which several projects of noise screens have already been completed. $30 \mathrm{~m}$ wide road with two lanes and an emergency stop lane in each direction.

Accordingly, in a computer model, 4 linear sound sources are set corresponding to traffic flows that move along each lane. The height of the sound sources is $0.5 \mathrm{~m}$, which corresponds to the height of the acoustic center of the traffic stream. The height of the screen is $5 \mathrm{~m}$, located on the edge of the road on one side (Fig. 2).

For each sound source, the source productivity parameter $Q=0.01 \mathrm{~m}^{2} / \mathrm{s}$ was set, which did not affect the research results, since the screen efficiency within the linear model does not depend on the level of sound energy created by sound sources.

The study of changes in sound levels with a screen was carried out at points at a distance of 0 to $20 \mathrm{~m}$ behind the screen (in increments of $0.25 \mathrm{~m}$ ) and a height of $1.5 \mathrm{~m}$. A land surface with a sound absorption coefficient of 1 corresponding to the surface of the ground covered with grass was modeled on the screen [18].

The acoustically sound-absorbing screen had a section of a rectangle $5 \mathrm{~m}$ high and $0.1 \mathrm{~m}$ wide. This width corresponds to most noise screens built in Ukraine.

Sound-absorbing properties of the screen were set through the input acoustic impedance parameter of the front surface of the screen. All other screen surfaces were modeled acoustically rigid, that is, with infinite impedance. Such an approach in acoustics is justified when the acoustic impedance of an obstacle is three or more orders of magnitude higher than the acoustic impedance of the medium in which the acoustic wave propagates. 


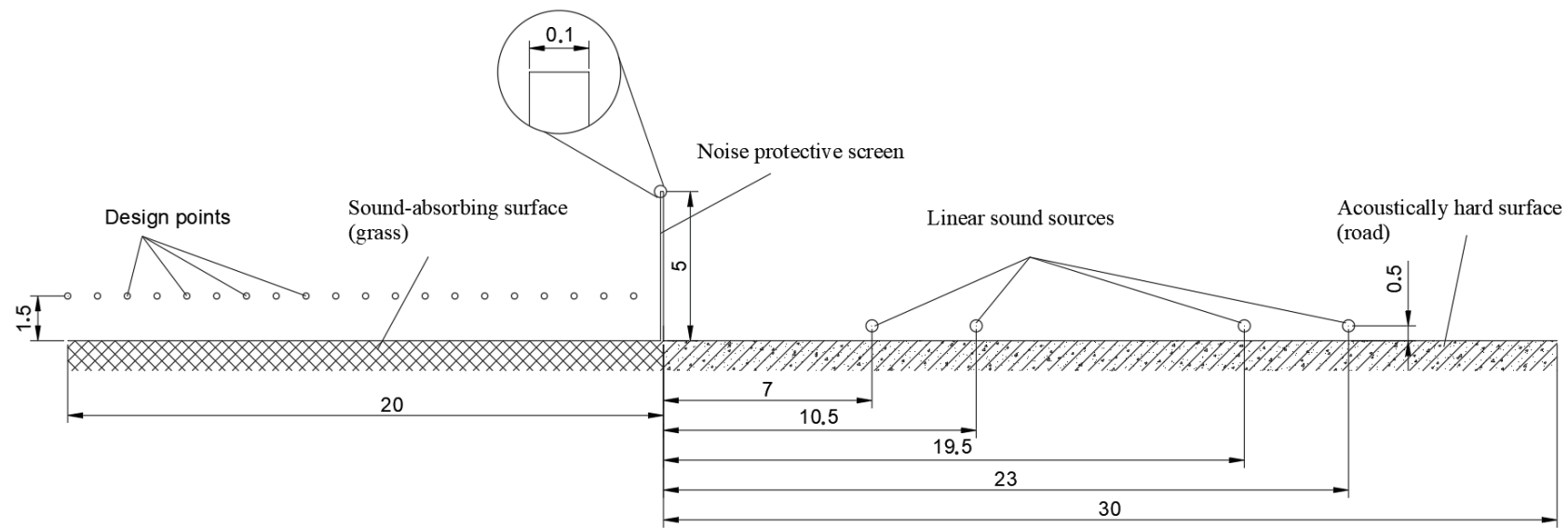

Fig. 2. The relative position of the noise source, screen and design points

The absorption coefficient of an acoustic wave in intensity was calculated from the known relation:

$$
\alpha=\frac{4 \cdot Z_{1} \cdot Z_{2}}{\left(Z_{1}+Z_{2}\right)^{2}},
$$

where $Z_{1}$ - impedance of the medium from which the acoustic wave propagates; $Z_{2}$ - input screen impedance.

Four sound absorption coefficients $\alpha$ were chosen for which the calculations were carried out (Table 1).

For each coefficient, a screen model was built and the distribution of acoustic pressures at frequencies of $31.5 \mathrm{~Hz}$, $63 \mathrm{~Hz}, 125 \mathrm{~Hz}, 250 \mathrm{~Hz}, 500 \mathrm{~Hz}$ and $1000 \mathrm{~Hz}$ was reproduced. The sound pressure levels of the absolutely reflecting

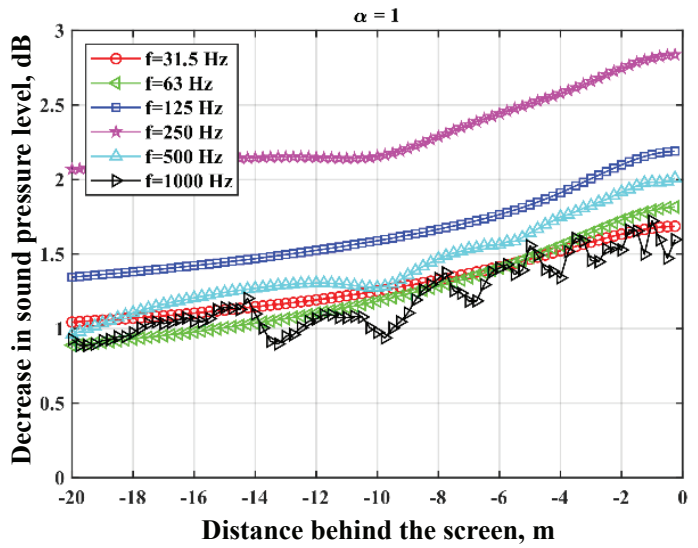

a

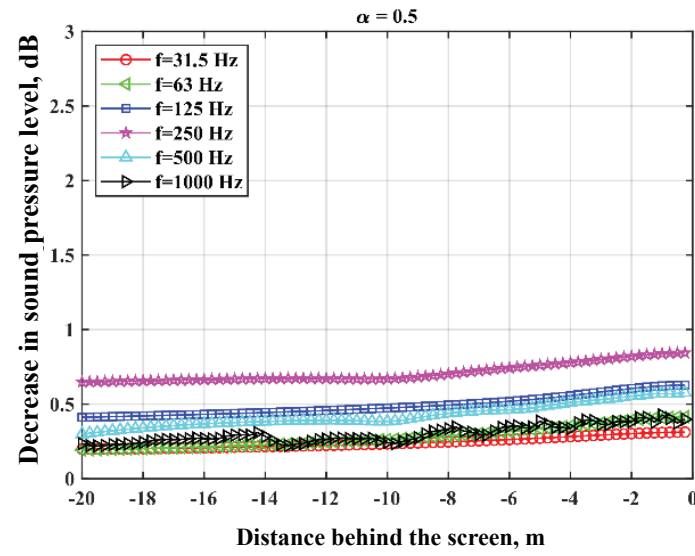

screen $(\alpha=0)$ and the impedance screen are compared with the corresponding sound absorption coefficient.

Table 1

Sound absorption coefficients and acoustic input impedance of the screen

\begin{tabular}{|c|c|c|c|c|}
\hline$Z_{1}, \mathrm{~kg} /\left(\mathrm{m}^{2} \mathrm{~s}\right)$ & \multicolumn{4}{|c|}{411.6} \\
\hline$Z_{2,} \mathrm{~kg} /\left(\mathrm{m}^{2} \mathrm{~s}\right)$ & 411.6 & 792.3 & 2399.0 & 15630.0 \\
\hline$\alpha$ & 1 & 0.9 & 0.5 & 0.1 \\
\hline
\end{tabular}

6.2. Calculation results. Fig. $3, a-d$ shows the increase in the efficiency of the noise protective screen when applying sound-absorbing material to it (i. e., the difference in sound pressure level with a completely reflective surface of the screen and the sound-absorbing surface of the screen).

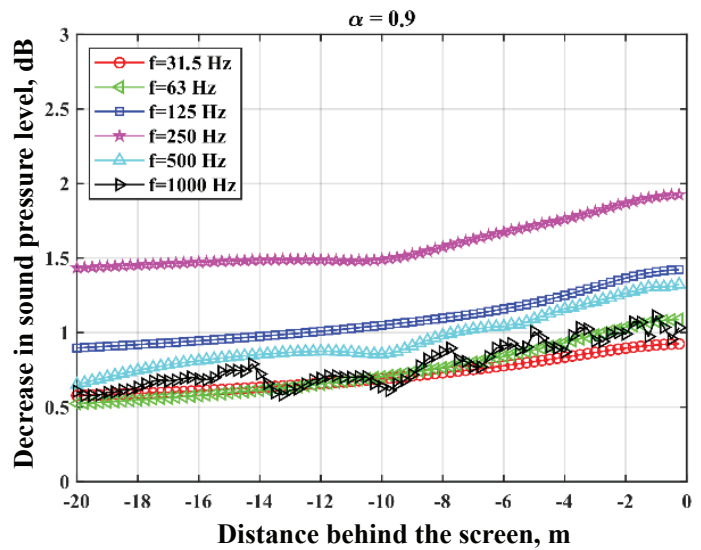
$b$

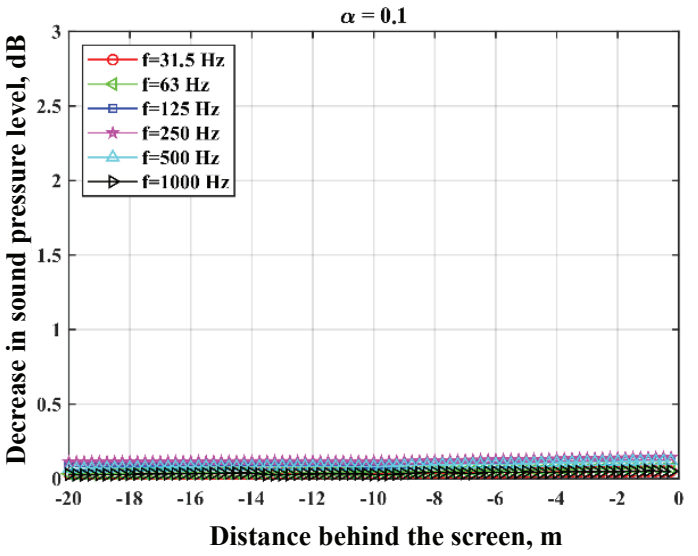

Fig. 3. Increasing the screen effectiveness due to sound absorption of the front side: $a-\alpha=1.0 ; b-\alpha=0.9 ; c-\alpha=0.5 ; d-\alpha=0.1$ 
Fig. 3, $a$ shows the maximum increase in the efficiency of the noise protective screendue to sound absorption. As it is possible to see, the screen efficiency ranges from $1.5 \mathrm{~dB}$ to $3 \mathrm{~dB}$, depending on the frequency. With increasing distance behind the screen, the effect of sound absorption on increasing the efficiency of the screen decreases and ranges from $1 \mathrm{~dB}$ to $2 \mathrm{~dB}$.

With a decrease in the sound absorption coefficient (Fig. 3, $b-d$ ), the increase in the efficiency of the screen monotonously decreases. And for a sound absorption coefficient of 0.5 , the increase in screen efficiency due to the sound-absorbing cladding is not more than $1 \mathrm{~dB}$.

6.3. Discussion of the results. To assess the effect of sound absorption, a $3 \mathrm{~m}$ high screen with a similar arrangement of sound sources and design points is also calculated (Fig. 3). The results of calculating the increase in screen efficiency due to sound absorption are shown in Fig. 4.

The calculation results show that the maximum increase in screen efficiency is $2.5 \mathrm{~dB}$, which is quite good coincides with the results shown in Fig. 3, $a$. It is possible to conclude that the increase in screen efficiency due to sound absorption is almost independent of the height of the screen.

In addition, the field around the screen is calculated as the oncoming of sound sources to the screen (Fig. 5).

The results of the effect of the sound-absorbing cladding of the screen on its effectiveness are shown in Fig. 6.

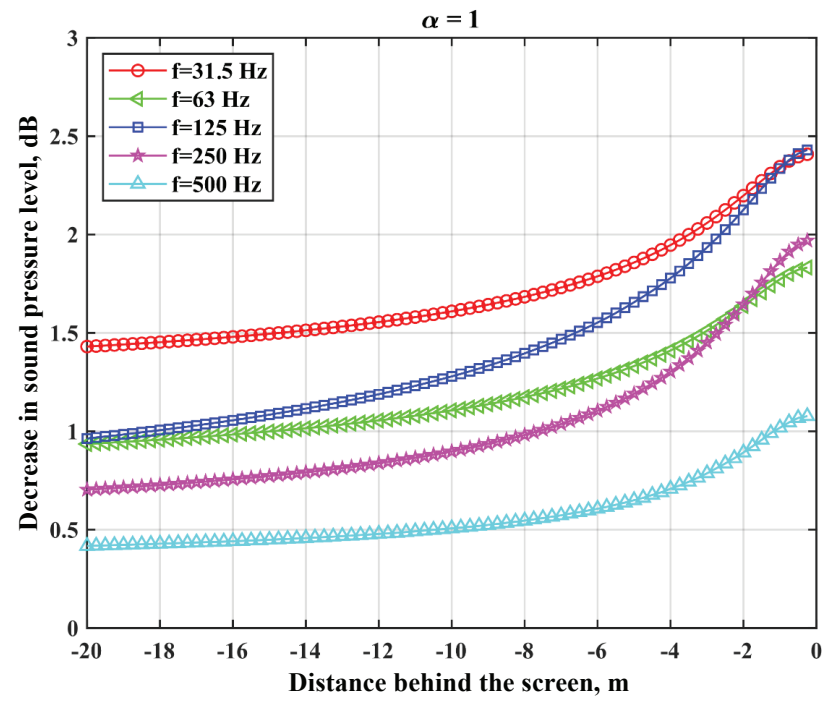

Fig. 4. Increasing the screen efficiency due to sound absorption of the front side with a screen height of $3 \mathrm{~m}$
As can be seen from Fig. 6, sound-absorbing cladding has increased screen efficiency by up to $5 \mathrm{~dB}$. Moreover, such an increase is characteristic of the low $(31.5 \mathrm{~Hz})$ of the considered frequencies. This method is quite promising because it allows to increase the screen efficiency at low frequencies by almost half (Fig. 7) due to the sound-absorbing cladding.

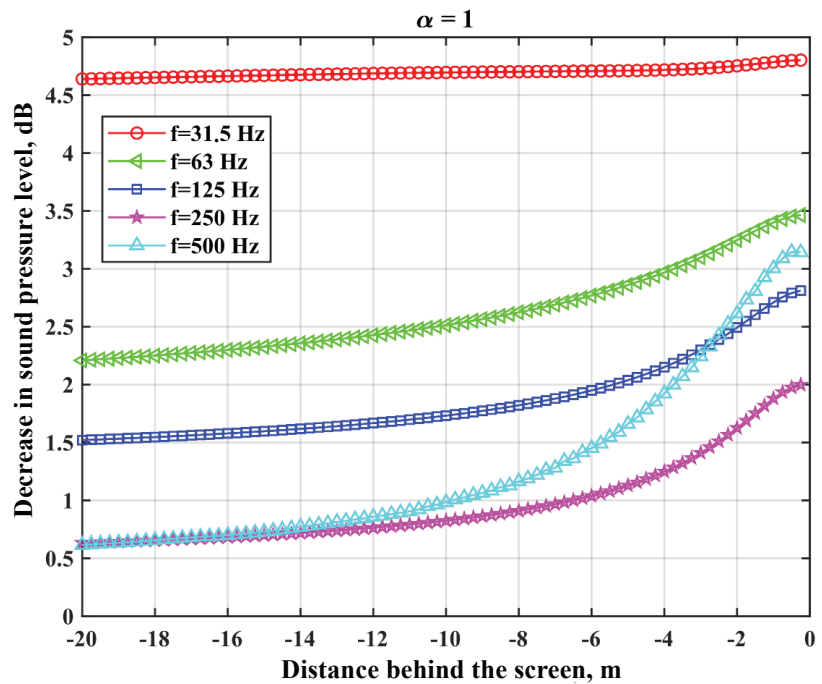

Fig. 6. Increasing the screen efficiency due to sound absorption of the front side with a screen height of $3 \mathrm{~m}$ and the ongoing of sound sources to the screen

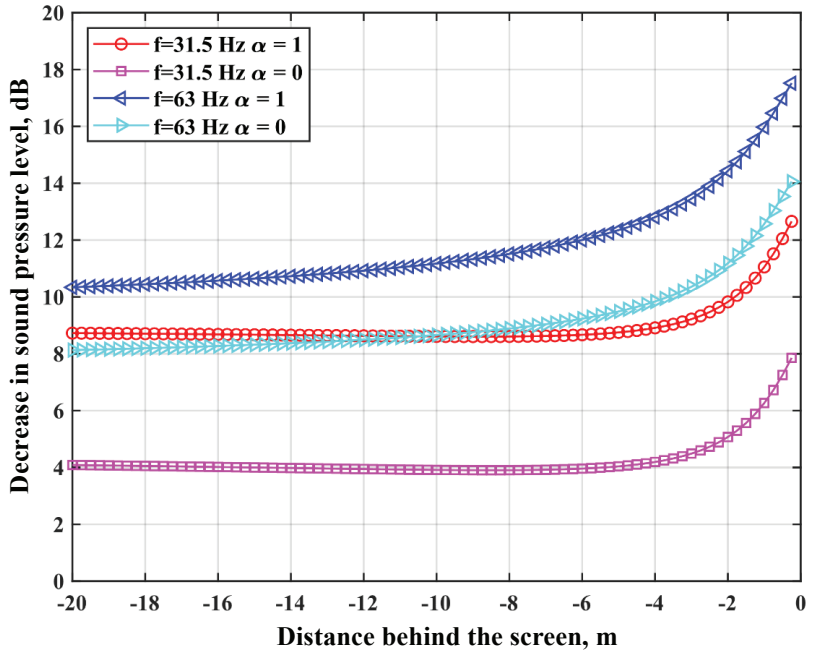

Fig. 7. Comparison of the effectiveness of acoustically rigid and sound-absorbing screens at low frequencies

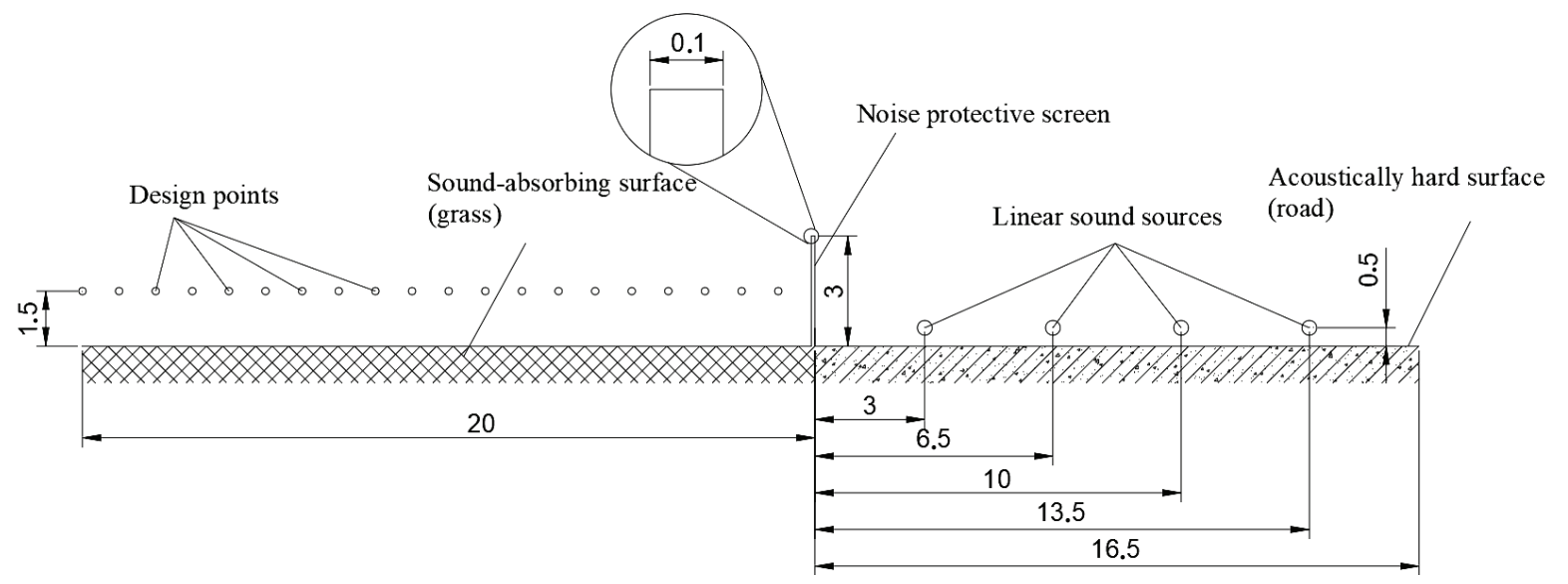

Fig. 5. The relative position of the approximate sources of noise, screen and design points 
According to the calculation results, it is possible to see that for points at a distance of more than $10 \mathrm{~m}$, the efficiency of a sound-reflecting screen $(\alpha=0)$ at a frequency of $31.5 \mathrm{~Hz}$ is $4 \mathrm{~dB}$, and that of a sound-absorbing $(\alpha=1)$ is more than $8 \mathrm{~dB}$. For high frequencies, this difference is less characteristic.

\section{SWOT analysis of research results}

Strengths. Studies have shown that the use of sound-absorbing cladding for noise screens can increase their effectiveness. It is revealed that the closer the screen is located to the sound source, the greater the influence of its sound-absorbing properties. It is shown that for low frequencies the increase in screen efficiency due to sound absorption can reach $5 \mathrm{~dB}$.

Weaknesses. The disadvantages of the study include the fact that at this stage only computer modeling of the sound field around the sound-absorbing screen is carried out.

Opportunities. In the future, it is necessary to pay attention to the analytical solution of the problem of finding the sound field around the impedance screen and conduct experimental studies in natural conditions or on physical models.

Such studies will allow in practice to prove the need for sound absorption, as a factor in increasing the efficiency of screens without changing their geometric dimensions.

Threats. Separate attention should be paid to the issue of protecting sound-absorbing elements of the screen from atmospheric influences. Usually, PVC films are used to protect against atmospheric precipitation, however, it is known that the use of films leads to a decrease in the sound absorption coefficient, therefore this issue requires a separate study.

\section{Conclusions}

1. As a result of the studies, it is found that the soundabsorbing properties of noise screens significantly affect:

- screen resolution to reduce noise levels;

- ability to increase the efficiency of the screen due to sound absorption and is almost independent of the height of the screen;

- when the screen approaches the noise source, the sound absorption factor becomes more significant to increase the efficiency of the screen.

The creation of screens with high-visibility properties at low frequencies is a promising direction for increasing the overall effectiveness of noise screens.

2. The maximum possible value of increasing the efficiency of the screen due to sound absorption is determined:

- for roads of international importance with a width of $30 \mathrm{~m}$ for a screen with a height of $5 \mathrm{~m}$, sound-absorbing cladding devices with a sound absorption coefficient of not less than 0.9 leads to an increase in efficiency by $1.0 \mathrm{~dB}$ to $2.5 \mathrm{~dB}$ depending on the frequency;

- for local roads with a width of not more than $15 \mathrm{~m}$, the maximum increase in the effectiveness of the noise protective screen is $5 \mathrm{~dB}$.

\section{References}

1. Zaets, V., Kotenko, S. (2017). Investigation of the efficiency of a noise protection screen with an opening at its base. EasternEuropean Journal of Enterprise Technologies, 5 (5 (89)), 4-11. doi: http://doi.org/10.15587/1729-4061.2017.112350

2. Gieva, E., Ruskova, I., Nedelchev, K., Kralov, I. (2018). An investigation of the influence of the geometrical parameters of a passive traffic noise barrier upon the noise reduction response.
AIP Conference Proceedings. AIP Publishing LLC, 2048 (1), 020020. doi: http://doi.org/10.1063/1.5082038

3. Farina, A., Fausti, P. (1995). Motorway traffic noise reduction by means of barriers: a design example based on prediction models and experimental verification. Available at: http://www. angelofarina.it/Public/Papers/074-ICA95.PDF

4. Manojkumar, N., Basha, K., Srimuruganandam, B. (2019). Assessment, Prediction and Mapping of Noise Levels in Vellore City, India. Noise Mapping, 6 (1), 38-51. doi: http://doi.org/10.1515/ noise-2019-0004

5. Directive, C. (1988). 89/106/EEC" Council Directive 89/106. EEC of 21 December 1988 on the approximation of laws, regulations and administrative provisions of the Member States relating to construction products. Available at: https://eur-lex.europa.eu/ legal-content/en/ALL/?uri=CELEX:31989L0106

6. Trokhymenko, M. P., Zaiets, V. P. (2010). Vplyv parametriv shumozakhysnykh ekraniv na yikh efektyvnist. Budivelni materialy, vyroby ta sanitarna tekhnika, 36, 71-76.

7. Maekawa, Z. (1968). Noise reduction by screens. Applied Acoustics, 1 (3), 157-173. doi: http://doi.org/10.1016/0003-682x(68)90020-0

8. Jonasson, H. G. (1972). Sound reduction by barriers on the ground Journal of Sound and Vibration, 22 (1), 113-126. doi: http:/ doi.org/10.1016/0022-460x(72)90849-8

9. Hewett, D. P., Langdon, S., Chandler-Wilde, S. N. (2014). A frequency-independent boundary element method for scattering by twodimensional screens and apertures. IMA Journal of Numerical Analysis, 35 (4), 1698-1728. doi: http://doi.org/10.1093/imanum/dru043

10. François, S., Schevenels, M., Degrande, G., Borgions, J., Thyssen, B. (2008). A 2.5 D finite element-boundary element model for vibration isolating screens. Proceedings of ISMA2008 International Conference on Noise and Vibration Engineering, 5, 2765-2776.

11. Ganesh, M., Morgenstern, C. (2016). High-order FEM-BEM computer models for wave propagation in unbounded and heterogeneous media: Application to time-harmonic acoustic horn problem. Journal of Computational and Applied Mathematics, 307, 183-203. doi: http://doi.org/10.1016/j.cam.2016.02.024

12. Kouroussis, G., Van Parys, L., Conti, C., Verlinden, O. (2014). Using three-dimensional finite element analysis in time domain to model railway-induced ground vibrations. Advances in Engineering Software, 70, 63-76. doi: http://doi.org/10.1016/j.advengsoft.2014.01.005

13. Sun, W., Liu, L., Yuan, H., Su, Q. (2019). Influence of Top Shape on Noise Reduction Effect of High-Speed Railway Noise Barrier IOP Conference Series: Materials Science and Engineering, 493, 012043. doi: http://doi.org/10.1088/1757-899x/493/1/012043

14. Monazzam, M. R., Naderzadeh, M., Momen, S., Fard, B. (2012) An optimization process for a T-shaped noise barrier coated by primitive root diffuser equipped with perforated sheets. Journal of Food, Agriculture E Environment, 10 (1), 993-996.

15. Hayek, S. I. (1990). Mathematical modeling of absorbent highway noise barriers. Applied Acoustics, 31 (1-3), 77-100. doi: http://doi.org/10.1016/0003-682x(90)90054-x

16. Ding, L., Van Renterghem, T., Botteldooren, D. (2009). Estimating the effect of semi-transparent traffic noise barrier with ultra weak variational formulation. 8th European conference on Noise Control (Euronoise 2009): Action on noise in Europe, 1369-1375.

17. Luo, W.-J., Liu, G.-Y. (2017). Study on the Noise Reduction of Sound Absorption Noise Barrier. Materials Science and Engineering. doi: http://doi.org/10.1142/9789813226517 0133

18. ISO 9613-2 (1996). Attenuation of Sound During Propagation Outdoors-Part 2: A General Method of Calculation. Geneva: ISO. Available at: https://www.iso.org/standard/20649.html

Didkovskyi Vitalii, Doctor of Technical Sciences, Professor, De partment of Acoustic and Multimedia Electronic Systems, National Technical University of Ukraine «Igor Sikorsky Kyiv Polytechnic Institute», Ukraine, ORCID: http://orcid.org/0000-0002-0807-822X, e-mail:v.didkovskyi@gmail.com

Zaets Vitaly, PhD, Associate Professor, Department of Acoustic and Multimedia Electronic Systems, National Technical University of Ukraine «Igor Sikorsky Kyiv Polytechnic Institute», Ukraine, ORCID: http://orcid.org/0000-0002-2232-9187,e-mail: zaetsv@i.ua

Kotenko Svetlana, PhD, Junior Researcher, Department of Building Physics and Energy Efficiency, State Enterprise «State Research Institute of Building Constructions», Kyiv, Ukraine, ORCID: http:// orcid.org/0000-0001-6804-1413, e-mail: catdontlike@gmail.com 